$\begin{array}{r}\text { Phinisi Integration Review } \\ \text { Vol. 2, No.1, Februari 2019 Hal 146-164 } \\ \text { Website: http://ojs.unm.ac.id/pir } \\ \text { p-ISSN: 2614-2325 dan e-ISSN: 2614-2317 } \\ \hline\end{array}$

\title{
Implementasi Permendikbud No. 82 Tahun 2015 Tentang Pencegahan dan Penanggulangan Tindak Kekerasan di Lingkungan Satuan Pendidikan di SMP Telkom Makassar
}

\author{
Sabaruddin $^{(1),}$ \\ Pendidikan Hukum dan Kewarganegaraan, Fakultas Ilmu Sosial Universitas Negeri Makassar \\ email:91sabar@gmail.com
}

\begin{abstract}
Abstrak. Penelitian ini bertujuan untuk mengetahui tingkat pemahaman guru-guru tentang implementasi Permendikbud No. 82 Tahun 2015 tentang pencegahan dan penanggulangan tindak kekerasan di lingkungan satuan pendidikan di SMP Telkom Makassar, kendala-kendala yang menyebabkan sehingga implementasi Permendikbud No. 82 Tahun 2015 tentang pencegahan dan penanggulangan tindak kekerasan di lingkungan satuan pendidikan di SMP Telkom Makassar sehingga belum maksimal, serta langkah-langkah apa saja yang di lakukan oleh SMP Telkom Makassar dalam mencegah dan menanggulangi tindak kekerasan yang terjadi di lingkungan satuan pendidikan. Penelitian ini termasuk penelitian yang menggunakan metode deskripsi kualitatif. Data diperoleh melalui responden dan wawancara dengan informan yang terdiri dari wali kelas, guru bidang studi, dan guru BK, juga melalui observasi dan dokumentasi. Hasil dari penelitian ini menunjukkan bahwa : 1) Tingkat pemahaman guru-guru di SMP Telkom makassar tentang Permendikbud Nomor 82 Tahun 2015 berada pada kategoti kurang baik. 2) Yang menjadi kendala sehingga tindak kekerasan di SMP Telkom Makassar belum mampu di cegah di sebabkan oleh dua faktor, yaitu faktor internal dan faktor eksternal. Faktor internal dari guru berupa (a) kurangnya pengetahuan guru bahwa kekerasan baik fisik maupun psikis tidak efektif untuk memotivasi siswa atau merubah perilaku, (b) Adanya masalah psikologis yang menyebabkan hambatan dalam mengelola emosi hingga guru yang bersangkutan menjadi lebih sensitif dan reaktif . Faktor internal dari siswa berupa (a) Kurangnya sikap toleransi, sulit mengotrol emosi dan kurangnya sikap tanggungjawab (b) Masa pertumbuhan remaja yang dialami oleh siswa. Sedangkan faktor eksternalnya berupa (a) Adanya tekanan kerja atau target yang harus dipenuhi oleh guru (b) Faktor lingkungan tempat tinggal siswa. 3) Upaya yang telah dilakukan oleh SMP Telkom Makassar untuk mencegah dan menanggulangi terjadinya tindak kekerasan berupa kegiatan MPLS atau Masa Pengenalan Lingkungan Sekolah bagi siswa baru, dan sistem kredit poin apabila ada pelanggaran oleh siswa dan pengurangan poin jika siswa berbuat kebaikan.
\end{abstract}

Kata Kunci: Implementasi; Pencegahan; Penaggulangan; Tindak Kekerasan

Abstract. The study aims at examining the degree of teachers' understanding on the
implementation of Permendikbud No. 82 Tahun 2015 on prevention and overcoming
violence within the education unit at SMP Telkom Makassar, the constraints that cause
the implementation of Permendikbud No.82 Tahun 2015 on prevention and overcoming
violence within the education unit at SMP Telkom Makassar have not yet maximal, and
the steps conducted by SMP Telkom Makassar in preventing and overcoming violence
that happen in education unit. This study employed descriptive qualitative method. Data 
were obtained by conducted interview to the respondents who consisted of homeroom teacher, subject teachers, and guidance and counseling teachers; conducted observation as well as documentation. The results of the study reveal that 1) the degree of teachers' understanding at SMP Telkom Makassar on Permendikbud No.82 Tahun 2015 is in poor category; 2) the constraints of violence at SMP Telkom Makassar that have not been prevented caused by two factors, namely the internal and external factors. The internal factors from the teachers are (a) lack of knowledge of teachers that physical violence and psychological violence is not effective to motivate students to change their behaviors, (b) there are psychological problems as the constraints to manage emotions so teachers become more sensitive and reactive. The internal factors from the students are (a) lack of tolerance, difficulty in controling emotion, and lack of responsibility, (b) adolescence growth period experienced by students. While the external factors are (a) pressure of working or target to be fulfilled by teachers, (b) environmental factor where students live; 3) efforts conducted by SMP Telkom Makassar to prevent and overcome violence are MPLS activity or orientation for new students, and point credit system when there is violation done by students and point deduction when students made good deed.

Keywords: Implementation; Prevention; Overcoming; Violence

Ini adalah artikel dengan akses terbuka dibawah licenci CC BY-NC-4.0 (https://creativecommons.org/licenses/by-nc/4.0/ ).

\section{PENDAHULUAN}

Pendidikan adalah wadah untuk mencerdaskan kehidupan bangsa sebagaimana yang diamanatkan dalam Pembukaan UUD NRI 1945. Amanah ini bukan perkara yang bisa dikesampingkan dibanding perkara lain, karena lewat pendidikan inilah generasi indonesia dibentuk. Melalui sekolah, pemerintah merancang sedemikian rupa agar generasi masa depan mendapatkan pendidikan yang nyaman dan berkualitas karena kelak di tangan generasi inilah indonesia akan di titipkan.

Pendidikan nasioanal berfungsi mengembangkan kemampuan dan membentuk watak serta peradaban bangsa yang bermartabat dalam rangka mencerdaskan kehidupan bangsa, bertujuan untuk berkembangnya potensi peserta didik agar menjadi manusia yang beriman dan bertaqwa kepada Tuhan Yang Maha Esa, berakhlak mulia, sehat, berilmu, cakap, kreatif, mandiri, dan menjadi warga negara yang demokratis serta bertanggung jawab. (UU RI Nomor 20 Tahun 2003 tentang Sistem Pendidikan Nasional)

Sekolah sejatinya adalah taman bermain yang nyaman untuk peserta didik agar mereka betah dalam menimba ilmu. Sekolah diharapkan mampu mencegah dan menanggulangi hal-hal yang tidak perlu dan tak ada kaitannya dengan pendidikan seperti kekerasan guru terhadap peserta didik, kekerasan peserta didik terhadap guru, atau kekerasan antara peserta didik dengan peserta didik lainnya.

Akhir-akhir ini baik di media massa maupun media elektronik seringkali kita disuguhi berita tentang kejadian-kejadian tidak pantas yang di contohkan oleh ekosistem sekolah. Dan selama ini belum ada penangananan yang terstuktur untuk menangani kasus-kasus tindak kekerasan ini. Selama ini penanganan yang dilakukan sifatnya hanya dari satu kasus ke kasus lainnya (kasuistik), jika dianggap memenuhi unsur pidana maupun perdata langsung masuk ke ranah hukum tanpa di pandang sebagai masalah pendidikan.

Kekerasan yang dimaksud tidak hanya sebatas memukul atau melukai tubuh orang lain. Namun, kekerasan tidak sesempit itu. Seperti yang dirumuskan dalam world report on violence and health (WRVH), menyebutkan kekerasan sebagai penggunaan kekuatan fisik atau ancaman secara sengaja kepada diri sendiri, orang lain, maupun kelompok yang mengakibatkan cedera, kematian, gangguan psikis atau trauma, gangguan perkembangan, ataupun deprivasi. Sedangkan kekerasan menurut American Psychological Association (APA) adalah bentuk ekstrim dari agresi, seperti penyerangan, pemerkosaan, atau pembunuhan. 
Ada beberapa faktor yang dapat menyebabkan kekerasan dalam diri seseorang timbul. Apakah karena game, tayangan kekerasan di TV, keadaan dan lain sebagainya. Karena itu maka sekolah sebaiknya mengambil tindakan lebih pro-aktif dalam menangani kekerasan di sekolah. Hal pertama yang perlu dilakukan adalah membentuk sekolah agar lingkungannya menjadi kondusif, baik untuk para murid, guru dan staff. Sekolah yang kondusif mendukung lingkungan yang aman, pendidikan yang baik, dan tingkah laku yang terpuji. Program sekolah yang baik akan tergantung pada berbagai faktor seperti keamanan, hubungan sosial yang sehat, emosional dan perkembangan akademik yang baik.

Dalam sebuah riset yang dilakukan LSM Plan International dan International Center for Research on Women (ICRW) yang dirilis awal Maret 2015 ini menunjukkan fakta mencengangkan terkait kekerasan anak di sekolah. Terdapat $84 \%$ anak di Indonesia mengalami kekerasan di sekolah. Angka tersebut lebih tinggi dari tren di kawasan Asia yakni $70 \%$.

(http://news.liputan6.com/read/2191106/surveiicrw-84-anak-indonesia-alami-kekerasan-disekolah)

Padahal Indonesia memiliki sejumlah peraturan perundang-undangan yang melindungi anak dari tindak kekerasan. Seperti UU Nomor 35 Tahun 2014 tentang Perlindungan Anak, Instruksi Presiden Nomor 5 Tahun 2014 tentang Gerakan Nasional Anti-kejahatan Seksual terhadap anak, dan UU Nomor 11 Tahun 2012 tentang Sistem Peradilan Pidana Anak.

Namun penerapan perangkat hukum ini masih terbentur beragam kendala seperti ketidaktahuan masyarakat dan kurangnya komitmen pemerintah daerah. Penerapan yang belum optimal ini membuat anak-anak di Indonesia belum sepenuhnya terlindungi.

Kekerasan dapat terjadi dimana saja, termasuk di sekolah. Sebagai salah satu satuan pendidikan setingkat SMP yang ada di kota Makassar keberadaan SMP Telkom Makassar sudah menjalankan fungsi proses pembelajaran sejak tahun 2015, sehingga satuan pendidikan tercatat sebagai wadah untuk membina dan mencerdaskan para calon generasi pengisi kemerdekaan di masa depan. Seperti sekolah pada umumnya, SMP Telkom Makassar juga tak terlepas dari tindak kekerasan, baik itu kekerasan fisik maupun non fisik. Seperti misalnya kasus Fadhil Athallah (kelas VII C) dan Muhammad Arjun Nurfaat (Kelas VII A) pada 24 juli 2017, kejadian ini bermula ketika Fadhil melempar penghapus ke arah Arjun dengan tidak sengaja, Arjun pun marah karena merasa tidak bersalah, akhirnya Arjun mendorong Fadhil sehingga jatuh ke lantai. Kasus ini di selesaikan guru BK dengan keduanya saling meminta maaf. Atau kasus antara Amelia Ramadhani (Kelas VII C) dengan teman-teman kelasnya pada 9 maret 2017. Kejadian ini bermula ketika Amel tidak nyaman dengan singgungan atau bercandaan temantemannya seperti yang dilakukan oleh Muhammad Fahrul, Muhammad Reza, Muhammad Fathir Arhaj, Muhammad Khairul Imam, dan teman-temannya yang lain kepada dirinya. Amelia merasa tidak nyaman lagi di kelas karena teman-temannya selalu mencelanya sambil tertawa. Kasus ini diselesaikan dengan teman-temannya meminta maaf kepada Amelia dan teman-temannya berjanji tidak mengulangi lagi perbuatannya. Dan masih banyak kasus kekerasan lainnya, baik itu kekerasan fisik maupun kekerasan non fisik. (Dokumentasi guru BK, 30 April 2018)

Mencermati kenyataan tersebut di atas dapatlah dinyatakan bahwa belum terlihat jelas pola yang terstruktur dan tersistematis dalam mencegah atau menanggulangi kasus kekerasan yang terjadi di SMP Telkom Makassar, baik itu kekerasan fisik maupun kekerasan non fisik. Padahal dalam Permendikbud No. 82 Tahun 2015 pasal 10 ayat (1) poin b misalnya, dikatakan bahwa satuan pendidikan wajib melaporkan kepada orangtua/wali peserta didik setiap tindak kekerasan yang melibatkan peserta didik baik sebagai korban maupun pelaku. Padahal selama ini keberadaan SMP telkom dinilai telah dikenal luas oleh sebagian besar kalangan masyarakat di kota Makassar, lantaran sekolah tersebut berafiliasi di bawah naungan PT Telkomsel anak perusahaan BUMN. Sebagai konsekuensi satuan pendidikan SMP swasta yang di kenal luas, semestinya kasus-kasus kekerasan di lingkungan sekolah tersebut bisa dieliminer.

Beberapa hipotesis bisa diajukan untuk menjelaskan fenomena kekerasan yang terjadi dalam dunia satuan pendidikan. Pertama, kekerasan dalam pendidikan bisa muncul sebagai akibat adanya pelanggaran yang disertai dengan hukuman, terutama fisik. Kedua, kekerasan dalam pendidikan bisa diakibatkan oleh buruknya sistem dan kebijakan pendidikan yang berlaku. Ketiga, kekerasan dalam 
pendidikan mungkin pula dipengaruhi oleh lingkungan masyarakat dan tayangan media massa. Keempat, kekerasan bisa jadi merupakan refleksi dan perkembangan kehidupan masyarakat yang mengalami pergeseran cepat, sehingga meniscayakan timbulnya sikap instant solution dan jalan pintas. Dan, kelima, kekerasan mungkin pula dipengaruhi oleh latar belakang sosial-ekonomi pelaku.

Kekerasan dalam pendidikan merupakan perilaku melampaui batas kode etik dan aturan dalam pendidikan, baik dalam bentuk fisik maupun pelecehan atas hak seseorang. Pelakunya bisa siapa saja: pimpinan sekolah, guru, staf, murid, orang tua atau wali murid, bahkan masyarakat.

Dari pemaparan diatas, penulis mencoba meneliti implementasi Permendikbud No. 82 Tahun 2015 di SMP Telkom Makassar ini untuk melihat sejauh mana efektivitas pelaksanaan Permendikbud ini.

\section{METODE PENELITIAN}

\section{a. Jenis Penelitian dan Lokasi Penelitian}

Jenis penelitian ini adalah kualitatif yang menggambarkan dan mendeskripsikan upaya-upaya pencegahan dan penanggulangan tindak kekerasan di lingkungan sekolah, khususnya bagi pelaku-pelaku pendidikan dilingkungan sekolah SMP Telkom Makassar secara mendalam, guna menghasilkan data deskriptif bersifat uraian kata-kata atau maknamakna tertulis dari orang-orang atau responden yang diteliti dan dapat dipercaya serta memilih informan dari pihak sekolah yang memiliki pengetahuan lebih terhadap upaya pencegahan dan penanggulangan tindak kekerasan dilingkungan sekolah.

Pendekatan penelitian yang dipilih adalah survei terbatas, yakni penelitian hanya berlangsung di satu sekolah di kota Makassar Provinsi Sulawesi Selatan, yaitu SMP Telkom Makassar. Dengan maksud agar dapat mendeskripsikan dan menginterpretasikan data dalam keadaan atau peristiwa sebagaimana adanya, sehingga bersifat mengungkap fakta.

\section{b. Fokus Penelitian}

Yang menjadi fokus dalam penelitian ini adalah upaya pencegahan dan penanggulangan tindak kekerasan di sekolah, yang mencakup : upaya pencegahan dan upaya penanggulangan di tindakan kekerasan dilingkungan SMP Telkom Makassar.

\section{c. Deskripsi Fokus}

Agar dicapai kesamaan persepsi dan pengertian mengenai fokus penelitan, berikut ini akan dikemukakan deskripsi fokus penelitian mengenai beberapa aspek:

Tingkat pemahaman adalah derajat pengetahuan satuan pendidikan tehadap permendikbud No. 82 Tahun 2015.

Prosedur penanganan adalah langkahlangkah yang ditempuh oleh SMP Telkom Makassar dalam mencegah dan menanggulangi tindak kekerasan dilingkungan satuan pendidikan.

Kendala yang dihadapi adalah masalahmasalah yang muncul di SMP Telkom Makassar dalam mencegah dan menanggulangi tindak kekerasan dilingkungan satuan pendidikan.

\section{d. Informan}

Informan yang dipilih dalam penelitian ini dipilih secara representatif (mewakili) berdasarkan metode Purpossive Sampling yaitu teknik penentuan sampel dengan pertimbangan dan tujuan tertentu yang didasarkan atas ciri-ciri tertentu yang dipandang mempunyai sangkut paut yang erat dengan ciri-ciri populasi yang sudah diketahui sebelumnya. Adapun sampel yang akan dipilih peneliti adalah guru-guru di SMP Telkom Makassar.

Sedangkan untuk menjaring data, maka ditetapkan informan guna memberikan penilaian (assesment) mengenai derajat implementasi Permendikbud No. 82 Tahun 2015 tentang pencegahan dan penanggulangan tindak kekerasan dilingkungan satuan pendidikan di SMP Telkom Makassar. Penetapan informan dilakukan dengan mengacu pada akurasi hasil penyusunan indeks seperti yang disarankan oleh Arikunto dengan menetapkan besarnya sampel apabila subjek kurang dari 100, lebih baik diambil semua sehingga penelitiannya penelitian populasi. Jika subjeknya lebih besar dapat diambil antara 20-25 \% (Arikunto, 2002). Ini berarti bahwa $19+2=21$. Responden ini akan diambilkan dari guru-guru mata pelajaran ditambah dengan guru-guru BK. 


\section{e. Teknik Pengumpulan Data}

Teknik pengumpulan data merupakan langkah yang paling strategis dalam penelitian. Hal ini karena tujuan utama dari penelitian itu sendiri adalah memperoleh data. Dengan demikian, maka tanpa mengetahui teknik pengumpulan data, maka penulis tidak akan memperoleh data yang memenuhi standar. Untuk mendapatkan data yang relevan dengan masalah yang mau diteliti dalam penelitian digunakan 3 (tiga) teknik pengumpulan data yaitu :

Wawancara dan angket yang dilakukan diharapkan mendapat informasi yang sebenarnya mengenai Pencegahan dan Penanggulangan Tindak Kekerasan di SMP Telkom Makassar yang dapat melengkapi penelitian ini. Wawancara dengan informan atau orang yang memberi informasi tentang situasi dan kondisi latar belakang penelitian, antara lain Guru BK di SMP Telkom Makassar. Data yang diperoleh dari informan yang mewakili guru BK adalah Sri Wahyuni dan Jauri Putra Sulaiman serta Wali Kelas di SMP Telkom Makassar. Wawancara dilakukan kepada wali kelas sebagai pihak yang pertama kali menangani jika terjadi tindak kekerasan di SMP Telkom Makassar. Data yang diperoleh dari informan yang mewakili wali kelas adalah Agus Supriadi (8A), Ridwan (7B), Nurul Insani (8D), Irma Widiany (9D), Mursalim (7F).

Dalam melakukan wawancara peneliti mempergunakan pedoman wawancara (interview guide). Pedoman wawancara dimaksudkan untuk memberikan pengarahan kepada peneliti dalam melakukan wawancara. Penelitian ini akan dilakukan pada bulan Juli 2018.

Observasi yang dilakukan untuk melihat fakta yang terjadi dilapangan yaitu dengan pengamatan langsung pada kondisi yang terjadi dilokasi penelitian tersebut, yang dalam hal ini pengamatan terhadap pencegahan dan penanggulangan tindak kekerasan di SMP Telkom Makassar yang berkaitan dengan Implementasi Permendikbud No. 82 Tahun 2015. Pertimbangan peneliti untuk memilih metode observasi sebagai pengumpul data dalam penelitian ini yaitu agar dapat diperoleh data yang lengkap dan hasilnya dapat dipercaya kebenarannya. Observasi awal yang dilakukan oleh penulis pada bulan April 2018 sebagai masukan data awal dalam memulai suatu penelitian dengan melihat fenomena yang terjadi dalam Pencegahan dan Penanggulangan Tindak Kekerasan di SMP Telkom Makassar. Pada bulan April hingga bulan Mei 2018, penulis mengobservasi segala kegiatan Pencegahan dan Penanggulangan Tindak Kekerasan di SMP Telkom Makassar yang berkaitan dengan Implementasi Permendikbud No. 82 Tahun 2015 tentang Pencegahan dan Penanggulangan Tindak Kekerasan dilingkungan Satuan Pendidikan. (Foto Observasi terlampir)

Teknik dokumentasi dimaksudkan untuk mendapatkan catatan-catatan atau data yang berhubungan dengan Implementasi Permendikbud No. 82 Tahun 2015 tentang Pencegahan dan Penanggulangan Tindak Kekerasan dilingkungan Satuan Pendidikan, pemahaman guru tentang Implementasi Permendikbud No. 82 Tahun 2015 tentang Pencegahan dan Penanggulangan Tindak Kekerasan dilingkungan Satuan Pendidikan, kendala-kendala yang dihadapi dalam Pencegahan dan Penanggulangan Tindak Kekerasan di SMP Telkom, serta upaya-upaya yang dilakuan oleh SMP Telkom dalam Pencegahan dan Penanggulangan Tindak Kekerasan.

\section{f. Keabsahan Data}

Teknik yang digunakan untuk mengecek keabsahan data penelitian ini adalah dengan melakukan triangulasi. Pelaksanaan teknis dari langkah pengujian keabsahan ini akan memanfaatkan sumber, metode dan teori.

1. Triangulasi dengan sumber data dilakukan dengan membandingkan dan mengecek data yang diperoleh dari informan kemudian membandingkannya dengan data/informasi dari informan lain.

2. Triangulasi dengan metode dilalukan dengan membandingkan dan mengecek data yang diperoleh dari hasil pengumpulan data melalui metode tertentu kemudian membandingkannya dengan data/informasi dari metode yang berlainan.

3. Triangulasi dengan teori yaitu dengan membandingkan fakta dengan teori.

4. Member Check pada tahap penelitian ini hasil data yang telah dikumpulkan peneliti dicek ulang kembali kepada para informan untuk mengetahui keabsahan data yang telah dikumpulkan dan diinterpretasikan sehingga hasil penelitian dapat lebih akurat. 
Jadi peneliti menemui kembali informan pada suatu tempat lalu memperlihatkan hasil deskripsi. Kalau informan sudah menyetujui dan menganggap apa yang diuraikan sudah benar maka peneliti mengambil kesimpulan tentang hasil wawancara dan kuesioner.

\section{g. Teknik Analisis Data}

Teknik analisis data yang digunakan dalam penelitian ini adalah dengan metode deskriptif kualitatif, dimana peneliti menggambarkan, menarasikan dan menganalisis data secara sistematis tentang gambaran Tangibles, reliabilty, responsiveness, assurance, emphaty, persepsi guru-guru SMP Telkom Makassar. Analisis data dalam penelitian kualitatif dilakukan sejak sebelum memasuki lapangan, selama proses pengumpulan data dilingkungan, dan dilanjutkan secara intensif setelah data terkumpul. Data tersebut selanjutnya diolah dan diklasifikasikan melalui proses pengumpulan data, reduksi data, penyajian data, penarikan kesimpulan dan verifikasi.

Untuk lebih jelasnya gambaran tentang teknik analisis data, dapat dilihat pada penjelasan berikut.

1. Pengumpulan data yaitu dengan mengumpulkan data dan sumber data melalui teknik wawancara.

2. Reduksi data yaitu melakukan analisis data dengan cara merangkum, memilih hal-hal yang pokok, memfokuskan pada hal-hal yang penting dan membuat kategori sehingga memberikan gambaran yang jelas serta mempermudah peneliti dalam analisis data selanjutnya.

3. Penyajian data yaitu mengorganisasikan data, membuat kedalam pola, membuat uraian singkat, bagan, hubungan antar kategori sesuai dengan fokus penelitian.

4. Penarikan kesimpulan data yaitu penarikan kesimpulan. Ini merupakan temuan baru, dapat berupa deskriptif atau gambaran suatu objek yang belum jelas.

\section{A. Gambaran Umum SMP Telkom Makassar}

Dalam hasil penelitian ini, akan dikemukakan beberapa hal yang menjadi fokus permasalahan antara lain : (1) pemahaman guru-guru di SMP Telkom makassar tentang Permendikbud Nomor 82 Tahun 2015 (2) kendala yang dihadapi sehingga tindak kekerasan di SMP Telkom Makassar belum mampu di cegah (3) upaya yang dilakukan oleh SMP Telkom Makassar untuk mencegah dan menanggulangi terjadinya tindak kekerasan.

Sebelum peneliti memaparkan hasil penelitian, terlebih dahulu diuraikan gambaran umum SMP Telkom Makassar.

SMP Telkom Makassar merupakan salah satu satuan pendidikan swasta tingkat menengah yang terletak di Jln. A. P Pettarani No. 4 Kompleks Telkom, kelurahan Gunung Sari, Kecamatan Rappocini, Kota Makassar. Adapun rincian gambaran umum SMP Telkom Makassar dapat dilihat sebagai berikut :

NPSN : 69938800

Status : Swasta

Bentuk Pendidikan : SMP

Status Kepemilikan : Yayasan

SK Pendirian Sekolah : 421.2/085/DPK/II/2016

Tanggal SK Pendirian : 2016-02-29

SK Izin Operasional : 421.2/085/DPK/II/2016

Tanggal SK Izin Operasional : 421.2/085/DPK/II/2016

Luas Tanah Milik : 5691

Luas Tanah Bukan Milik : 0

\section{B. Hasil Penelitian}

a. Pemahaman satuan pendidikan di SMP Telkom Makassar terhadap Permendikbud Nomor 82 Tahun 2015

a. Pengetahuan satuan pendidikan terhadap Permendikbud No. 82 Tahun 2015

Pengetahuan satuan pendidikan terhadap Permendikbud No. 82 Tahun 2015 merupakan indikator penting untuk melihat sejauh mana tingkat pengetahuan satuan pendidikan dalam pencegahan dan penanggulangan tindak kekerasan di SMP Telkom Makassar. Berikut dikemukakan datanya :

Tabel 4.4 Pengetahuan pendidik terhadap Permendikbud No. 82 Tahun 2015 


\begin{tabular}{|c|c|c|c|c|c|}
\hline $\begin{array}{c}\text { N } \\
\text { o. }\end{array}$ & $\begin{array}{c}\text { Pilihan } \\
\text { Jawaban }\end{array}$ & $\begin{array}{c}\text { Bob } \\
\text { ot }\end{array}$ & $\begin{array}{c}\text { Frekue } \\
\text { nsi }\end{array}$ & $\begin{array}{c}\text { Prosenta } \\
\text { se }\end{array}$ & $\begin{array}{c}\text { Nil } \\
\text { ai }\end{array}$ \\
\hline 1 & $\begin{array}{c}\text { Sangat } \\
\text { Tahu }\end{array}$ & 4 & 0 & $0 \%$ & 0 \\
\hline 2 & Tahu & 3 & 1 & $4,8 \%$ & 3 \\
\hline 3 & $\begin{array}{c}\text { Sebagi } \\
\text { an }\end{array}$ & 2 & 1 & $4,8 \%$ & 2 \\
\hline 4 & $\begin{array}{c}\text { Tidak } \\
\text { Tahu }\end{array}$ & 1 & 19 & $90,4 \%$ & 19 \\
\hline & Jumlah & 21 & $100 \%$ & 24 \\
\hline
\end{tabular}

b. Pemahaman satuan pendidikan terhadap isi Permendikbud No. 82 Tahun 2015

Pemahaman satuan pendidikan terhadap Permendikbud No. 82 Tahun 2015 merupakan indikator penting untuk melihat sejauh mana tingkat pemahaman satuan pendidikan dalam pencegahan dan penanggulangan tindak kekerasan di SMP Telkom Makassar. Berikut dikemukakan datanya :

Tabel 4.6 Pemahaman pendidik terhadap Permendikbud No. 82 Tahun 2015

Sumber : Hasil analisis, 2018.

Nilai rata-rata untuk "Pengetahuan pendidik terhadap Permendikbud No. 82 Tahun 2015" berada pada angka " 1.15 " yang diperoleh dengan cara membagi jumlah perolehan nilai dengan jumlah responden. Apabila angka atau indeks "1.15" diinterpretasikan, maka pengetahuan pendidi terhadap Permendikbud No. 82 Tahun 2015 berada pada kategori "tidak baik" atau "D".

\begin{tabular}{|c|c|c|c|c|c|}
\hline No. & $\begin{array}{c}\text { Pilihan } \\
\text { Jawaban }\end{array}$ & Bobot & Frekuensi & Prosentase & Nilai \\
\hline \hline 1 & $\begin{array}{c}\text { Sangat } \\
\text { Paham }\end{array}$ & 4 & 0 & $\%$ & 0 \\
\hline 2 & Paham & 3 & 0 & $0 \%$ & 0 \\
\hline 3 & Sebagian & 2 & 2 & $9,5 \%$ & 4 \\
\hline 4 & $\begin{array}{c}\text { Tidak } \\
\text { Paham }\end{array}$ & 1 & 19 & $90,4 \%$ & 19 \\
\hline & Jumlah & & 21 & $100 \%$ & 23 \\
\hline
\end{tabular}

Sumber : Hasil analisis, 2018.

Tabel 4.5 Pengetahuan peserta didik terhadap Permendikbud No. 82 Tahun 2015

\begin{tabular}{|c|c|c|c|c|c|}
\hline $\mathrm{NO}$ & $\begin{array}{c}\text { Pilihan } \\
\text { Jawaba } \\
\mathrm{n}\end{array}$ & $\begin{array}{c}\text { Bobo } \\
t\end{array}$ & $\begin{array}{c}\text { Frekuen } \\
\mathrm{i}\end{array}$ & $\begin{array}{c}\text { Prosentas } \\
\mathrm{e}\end{array}$ & $\begin{array}{c}\text { Nila } \\
\text { i }\end{array}$ \\
\hline 1 & $\begin{array}{c}\text { Sangat } \\
\text { Tahu }\end{array}$ & 4 & 0 & $0 \%$ & 0 \\
\hline 2 & Tahu & 3 & 0 & $0 \%$ & 0 \\
\hline 3 & $\begin{array}{c}\text { Sebagia } \\
\mathrm{n}\end{array}$ & 2 & 3 & $6.6 \%$ & 6 \\
\hline 4 & $\begin{array}{l}\text { Tidak } \\
\text { Tahu }\end{array}$ & 1 & 42 & $93.4 \%$ & 42 \\
\hline & Jumlah & & 45 & $100 \%$ & 48 \\
\hline
\end{tabular}

Sumber : Hasil analisis, 2018.

Nilai rata-rata untuk "Pengetahuan peserta didik terhadap Permendikbud No. 82 Tahun 2015" berada pada angka "1.07" yang diperoleh dengan cara membagi jumlah perolehan nilai dengan jumlah responden. Apabila angka atau indeks "1.07" diinterpretasikan, maka pengetahuan peserta didik terhadap Permendikbud No. 82 Tahun 2015 berada pada kategori "tidak baik" atau "D".

Dari data tersebut pengetahuan satuan pendidikan tentang Permendikbud No. 82 Tahun 2015 tergolong rendah.
Nilai rata-rata untuk "Pemahaman pendidik terhadap Permendikbud No. 82 Tahun 2015" berada pada angka "1.1" yang diperoleh dengan cara membagi jumlah perolehan nilai dengan jumlah responden. Apabila angka atau indeks "1,1" diinterpretasikan, maka pengetahuan terhadap Pemahaman terhadap Permendikbud No. 82 Tahun 2015 berada pada kategori "kurang baik" atau "C".

Tabel 4.7 Pemahaman peserta didik terhadap Permendikbud No. 82 Tahun 2015

\begin{tabular}{|c|c|c|c|c|c|}
\hline $\begin{array}{c}\text { N } \\
\text { o }\end{array}$ & $\begin{array}{c}\text { Pilihan } \\
\text { Jawaban }\end{array}$ & $\begin{array}{c}\text { Bobo } \\
\mathrm{t}\end{array}$ & $\begin{array}{c}\text { Frekuens } \\
\mathrm{i}\end{array}$ & $\begin{array}{c}\text { Prosentas } \\
\mathrm{e}\end{array}$ & $\begin{array}{c}\text { Nila } \\
\mathrm{i}\end{array}$ \\
\hline \hline 1 & $\begin{array}{c}\text { Sangat } \\
\text { Paham }\end{array}$ & 4 & 0 & $0 \%$ & 0 \\
\hline 2 & Paham & 3 & 0 & $0 \%$ & 0 \\
\hline 3 & $\begin{array}{c}\text { Sebagia } \\
\mathrm{n}\end{array}$ & 2 & 2 & $4.4 \%$ & 4 \\
\hline 4 & $\begin{array}{c}\text { Tidak } \\
\text { Paham }\end{array}$ & 1 & 43 & $95.6 \%$ & 43 \\
\hline & Jumlah & & 45 & $1000 \%$ & 47 \\
\hline
\end{tabular}

Sumber : Hasil analisis, 2018.

Nilai rata-rata untuk "Pemahaman peserta didik terhadap Permendikbud No. 82 Tahun 2015" berada pada angka " 1.05 " yang diperoleh dengan cara membagi jumlah perolehan nilai dengan jumlah responden. Apabila angka atau indeks "1.05" diinterpretasikan, maka Pemahaman peserta didik terhadap 
Permendikbud No. 82 Tahun 2015 berada pada kategori "kurang baik" atau "C".

Dari data tersebut pemahaman satuan pendidikan terhadap Permendikbud No. 82 Tahun 2015 tergolong rendah.

c. Respon satuan pendidikan terhadap Permendikbud No. 82 Tahun 2015

Respon satuan pendidikan terhadap Permendikbud No. 82 Tahun 2015 merupakan indikator penting untuk melihat sejauh mana keseriusan pendidik dan peserta didik dalam pencegahan dan penanggulangan tindak kekerasan di SMP Telkom Makassar. Berikut dikemukakan datanya :

Tabel 4.8 Respon pendidik terhadap Permendikbud No. 82 Tahun 2015

\begin{tabular}{|c|c|c|c|c|c|}
\hline $\begin{array}{c}\text { No } \\
\cdot\end{array}$ & $\begin{array}{c}\text { Pilihan } \\
\text { Jawaba } \\
\mathrm{n}\end{array}$ & $\begin{array}{c}\text { Bobo } \\
\mathrm{t}\end{array}$ & $\begin{array}{c}\text { Frekuen } \\
\text { si }\end{array}$ & $\begin{array}{c}\text { Prosentas } \\
\mathrm{e}\end{array}$ & $\begin{array}{c}\text { Nila } \\
\mathrm{i}\end{array}$ \\
\hline \hline 1 & $\begin{array}{c}\text { Sangat } \\
\text { Setuju }\end{array}$ & 4 & 12 & $42,8 \%$ & 48 \\
\hline 2 & Setuju & 3 & 9 & $57,2 \%$ & 27 \\
\hline 3 & $\begin{array}{c}\text { Kurang } \\
\text { Setuju }\end{array}$ & 2 & 0 & 0 & 0 \\
\hline 4 & $\begin{array}{c}\text { Tidak } \\
\text { Setuju }\end{array}$ & 1 & 0 & 0 & 0 \\
\hline & Jumlah & & 21 & $100 \%$ & 75 \\
\hline
\end{tabular}

Sumber : Hasil analisis, 2018.

Nilai rata-rata untuk "Respon pendidik terhadap Permendikbud No. 82 Tahun 2015" berada pada angka "3.58" yang diperoleh dengan cara membagi jumlah perolehan nilai dengan jumlah responden. Apabila angka atau indeks " 3.58 " diinterpretasikan, maka respon pendidik terhadap Permendikbud No. 82 Tahun 2015 berada pada kategori "Sangat Baik" atau "A".

Tabel 4.9 Respon peserta didik terhadap Permendikbud No. 82 Tahun 2015

\begin{tabular}{|c|c|c|c|c|c|}
\hline No & Pilihan & Bobo & Frekuen & Prosentas & Nila \\
. & Jawaba & $\mathrm{t}$ & $\mathrm{si}$ & $\mathrm{e}$ & $\mathrm{i}$ \\
\hline
\end{tabular}

\begin{tabular}{|c|c|c|c|c|c|}
\hline & $\mathrm{n}$ & & & & \\
\hline 1 & $\begin{array}{c}\text { Sangat } \\
\text { Setuju }\end{array}$ & 4 & 34 & $75.6 \%$ & 136 \\
\hline 2 & Setuju & 3 & 11 & $24.4 \%$ & 33 \\
\hline 3 & $\begin{array}{c}\text { Kuran } \\
\mathrm{g} \\
\text { Setuju } \\
\text { Tidak } \\
\text { Setuju }\end{array}$ & 2 & 0 & $0 \%$ & 0 \\
\hline & Jumlah & & 45 & $100 \%$ & 169 \\
\hline
\end{tabular}

Sumber : Hasil analisis, 2018.

Nilai rata-rata untuk "Respon peserta didik terhadap Permendikbud No. 82 Tahun 2015" berada pada angka " 3.8 " yang diperoleh dengan cara membagi jumlah perolehan nilai dengan jumlah responden. Apabila angka atau indeks "3.8" diinterpretasikan, maka respon peserta didik terhadap Permendikbud No. 82 Tahun 2015 berada pada kategori "Sangat Baik" atau "A".

Dari data tersebut respon satuan pendidikan terhadap Permendikbud No. 82 Tahun 2015 tergolong sangat tinggi.

d. Sosialisasi Permendikbud No. 82 Tahun 2015

Sosialisasi Permendikbud No. 82 Tahun 2015 terhadap satuan pendidikan di SMP Telkom Makassar merupakan indikator penting dalam pencegahan dan penanggulangan tindak kekerasan di SMP Telkom Makassar. Berikut dikemukakan datanya :

Tabel 4.10 Sosialisasi Permendikbud No. 82 Tahun 2015 kepada pendidik

\begin{tabular}{|c|c|c|c|c|c|}
\hline $\begin{array}{c}\text { No } \\
\cdot\end{array}$ & $\begin{array}{c}\text { Pilihan } \\
\text { Jawaba } \\
\mathrm{n}\end{array}$ & $\begin{array}{c}\text { Bobo } \\
\mathrm{t}\end{array}$ & $\begin{array}{c}\text { Frekuen } \\
\text { si }\end{array}$ & $\begin{array}{c}\text { Prosentas } \\
\mathrm{e}\end{array}$ & $\begin{array}{c}\text { Nila } \\
\mathrm{i}\end{array}$ \\
\hline 1 & Pernah & 4 & 0 & $0 \%$ & 0 \\
\hline 2 & $\begin{array}{c}\text { Ragu- } \\
\text { ragu }\end{array}$ & 3 & 0 & $0 \%$ & 9 \\
\hline 3 & $\begin{array}{c}\text { Kuran } \\
\text { g Tahu }\end{array}$ & 2 & 5 & $23,8 \%$ & 10 \\
\hline 4 & $\begin{array}{c}\text { Tidak } \\
\text { Pernah }\end{array}$ & 1 & 16 & $76,1 \%$ & 16 \\
\hline & Jumlah & 21 & $100 \%$ & 26 \\
\hline
\end{tabular}

Sumber : Hasil analisis, 2018.

Nilai rata-rata untuk "Sosialisasi Permendikbud No. 82 Tahun 2015 kepada pendidik" berada pada angka " 1,24 " yang diperoleh dengan cara 
membagi jumlah perolehan nilai dengan jumlah responden. Apabila angka atau indeks " 1,24 " diinterpretasikan, maka sosialisasi Permendikbud No. 82 Tahun 2015 kepada pendidik berada pada kategori "Rendah" atau "C".

Tabel 4.11 Sosialisasi Permendikbud No. 82 Tahun 2015 kepada peserta didik

\begin{tabular}{|c|c|c|c|c|c|}
\hline $\begin{array}{c}\text { No } \\
\cdot\end{array}$ & $\begin{array}{c}\text { Pilihan } \\
\text { Jawaba } \\
\mathrm{n}\end{array}$ & $\begin{array}{c}\text { Bobo } \\
\mathrm{t}\end{array}$ & $\begin{array}{c}\text { Frekuens } \\
\mathrm{i}\end{array}$ & $\begin{array}{c}\text { Prosentas } \\
\mathrm{e}\end{array}$ & $\begin{array}{c}\text { Nila } \\
\mathrm{i}\end{array}$ \\
\hline \hline 1 & Pernah & 4 & 0 & $0 \%$ & 0 \\
\hline 2 & $\begin{array}{c}\text { Ragu- } \\
\text { ragu }\end{array}$ & 3 & 1 & $20 \%$ & 3 \\
\hline 3 & $\begin{array}{c}\text { Kurang } \\
\text { Tahu }\end{array}$ & 2 & 14 & $13.3 \%$ & 28 \\
\hline 4 & $\begin{array}{c}\text { Tidak } \\
\text { Pernah }\end{array}$ & 1 & 30 & $66.7 \%$ & 30 \\
\hline & Jumlah & & 45 & $100 \%$ & 61 \\
\hline
\end{tabular}

Sumber : Hasil analisis, 2018.

Nilai rata-rata untuk "Sosialisasi Permendikbud No. 82 Tahun 2015 kepada peserta didik" berada pada angka " 1,36 " yang diperoleh dengan cara membagi jumlah perolehan nilai dengan jumlah responden. Apabila angka atau indeks " 1,36 " diinterpretasikan, maka sosialisasi Permendikbud No. 82 Tahun 2015 kepada peserta didik berada pada kategori "Rendah" atau "C".

Dari data tersebut sosialisasi terhadap Permendikbud No. 82 Tahun 2015 kepada satuan pendidikan tergolong rendah.

e. Pendapat satuan pendidikan mengenai Permendikbud No. 82 Tahun 2015

Pendapat satuan pendidikan di SMP Telkom Makassar mengenai Permendikbud No. 82 Tahun 2015 merupakan indikator penting dalam pencegahan dan penanggulangan tindak kekerasan di SMP Telkom Makassar. Berikut dikemukakan datanya :

Tabel 4.12 Pendapat pendidik tentang Permendikbud No. 82 Tahun 2015

\begin{tabular}{|c|c|c|c|c|c|}
\hline No & $\begin{array}{c}\text { Pilihan } \\
\text { Jawaba } \\
\mathrm{n}\end{array}$ & $\begin{array}{c}\text { Bobo } \\
\mathrm{t}\end{array}$ & $\begin{array}{c}\text { Frekuens } \\
\mathrm{i}\end{array}$ & $\begin{array}{c}\text { Prosentas } \\
\mathrm{e}\end{array}$ & $\begin{array}{c}\text { Nila } \\
\mathrm{i}\end{array}$ \\
\hline
\end{tabular}

\begin{tabular}{|c|c|c|c|c|c|}
\hline 1 & $\begin{array}{c}\text { Sangat } \\
\text { Setuju }\end{array}$ & 4 & 14 & $66,6 \%$ & 56 \\
\hline 2 & Setuju & 3 & 7 & $33,3 \%$ & 21 \\
\hline 3 & $\begin{array}{c}\text { Ragu- } \\
\text { ragu }\end{array}$ & 2 & 0 & $0 \%$ & 0 \\
\hline 4 & $\begin{array}{c}\text { Tidak } \\
\text { Setuju }\end{array}$ & 1 & 0 & $0 \%$ & 0 \\
\hline & $\begin{array}{c}\text { Jumla } \\
\text { h }\end{array}$ & & 21 & $100 \%$ & 77 \\
\hline
\end{tabular}

Sumber : Hasil analisis, 2018.

Nilai rata-rata untuk "Pendapat pendidik mengenai Permendikbud No. 82 Tahun 2015" berada pada angka " 3,67 " yang diperoleh dengan cara membagi jumlah perolehan nilai dengan jumlah responden. Apabila angka atau indeks "3,67" diinterpretasikan, maka Pendapat pendidik mengenai Permendikbud No. 82 Tahun 2015 berada pada kategori "sangat tinggi" atau "A".

Tabel 4.13 Pendapat peserta didik mengenai Permendikbud No. 82 Tahun 2015

\begin{tabular}{|c|c|c|c|c|c|}
\hline $\begin{array}{c}\text { No } \\
\cdot\end{array}$ & $\begin{array}{c}\text { Pilihan } \\
\text { Jawaba } \\
\mathrm{n}\end{array}$ & $\begin{array}{c}\text { Bobo } \\
\mathrm{t}\end{array}$ & $\begin{array}{c}\text { Frekuens } \\
\mathrm{i}\end{array}$ & $\begin{array}{c}\text { Prosentas } \\
\mathrm{e}\end{array}$ & $\begin{array}{c}\text { Nila } \\
\mathrm{i}\end{array}$ \\
\hline 1 & $\begin{array}{c}\text { Sangat } \\
\text { Setuju }\end{array}$ & 4 & 31 & $68.9 \%$ & 124 \\
\hline 2 & Setuju & 3 & 14 & $31.1 \%$ & 42 \\
\hline 3 & $\begin{array}{c}\text { Ragu- } \\
\text { ragu }\end{array}$ & 2 & 0 & $0 \%$ & 0 \\
\hline 4 & $\begin{array}{c}\text { Tidak } \\
\text { Setuju }\end{array}$ & 1 & 0 & $0 \%$ & 0 \\
\hline & $\begin{array}{c}\text { Jumla } \\
\mathrm{h}\end{array}$ & 45 & $100 \%$ & 166 \\
\hline
\end{tabular}

Sumber : Hasil analisis, 2018.

Nilai rata-rata untuk "Pendapat peserta didik mengenai Permendikbud No. 82 Tahun 2015" berada pada angka " 3,69 " yang diperoleh dengan cara membagi jumlah perolehan nilai dengan jumlah responden. Apabila angka atau indeks "3,69" diinterpretasikan, maka pendapat peserta didik mengenai Permendikbud No. 82 Tahun 2015 berada pada kategori "sangat tinggi" atau "A".

Dari data tersebut pendapat satuan pendidikan mengenai Permendikbud No. 82 Tahun 2015 tergolong sangat tinggi.

\section{Upaya yang dilakukan oleh SMP Telkom Makassar untuk mencegah dan menanggulangi terjadinya tindak kekerasan}


Pencegahan dan penanggulangan tindak kekerasan menjadi indikator penting untuk melihat sejauh mana keseriusan SMP Telkom Makassar dalam menyelenggarakan pendidikan. Indikator yang digunakan adalah Permendikbud No. 82 Tahun 2015 pasal 8. Metode penarikan data yang digunakan adalah metode wawancara tertutup, berikut dikemukakan datanya :

a. Penciptaan lingkungan yang bebas dari tindak kekerasan

Tabel 4.14 Penciptaan lingkungan yang bebas dari tindak kekerasan

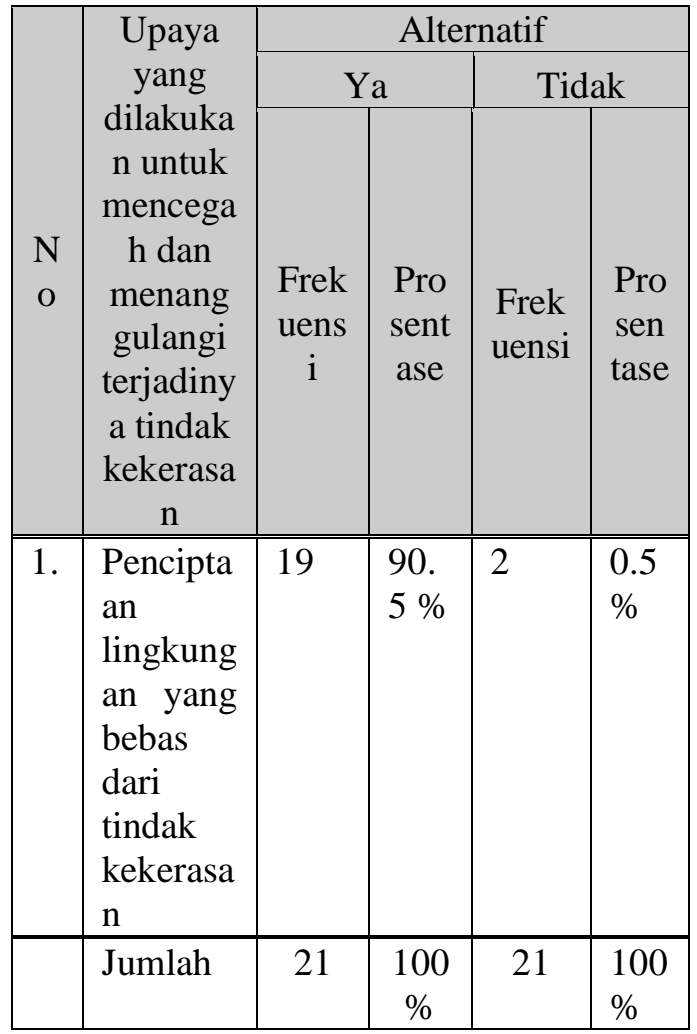

Sumber : Hasil analisis, 2018.

Nilai prosentase untuk "Penciptaan lingkungan yang bebas dari tindak kekerasan" berada pada angka "90.5\%" untuk yang berpendapat bahwa SMP Telkom Makassar telah menciptakan lingkungan yang bebas dari tindak kekerasan, dan " $0.5 \%$ " untuk yang berpendapat bahwa SMP Telkom Makassar belum menciptakan lingkungan yang bebas dari tindak kekerasan.

b. Pembangunan lingkungan yang aman, nyaman, dan menyenangkan

Tabel 4.15 Pembangunan lingkungan yang aman, nyaman, dan menyenangkan

\begin{tabular}{|l|l|l|}
\hline No & Upaya yang & Alternatif \\
\hline
\end{tabular}

\begin{tabular}{|c|c|c|c|c|c|}
\hline & dilakukan & \multicolumn{2}{|c|}{ Ya } & \multicolumn{2}{c|}{ Tidak } \\
\cline { 2 - 6 } & $\begin{array}{c}\text { untuk } \\
\text { mencegah dan } \\
\text { menanggulangi } \\
\text { terjadinya } \\
\text { tindak } \\
\text { kekerasan }\end{array}$ & $\begin{array}{c}\text { Fre } \\
\text { kue } \\
\text { nsi }\end{array}$ & $\begin{array}{c}\text { Pro } \\
\text { sen } \\
\text { tase }\end{array}$ & $\begin{array}{c}\text { Fre } \\
\text { kue } \\
\text { nsi }\end{array}$ & $\begin{array}{c}\text { Pro } \\
\text { sen } \\
\text { tase }\end{array}$ \\
\hline 2. & $\begin{array}{c}\text { Pembangunan } \\
\text { lingkungan } \\
\text { yang aman, } \\
\text { nyaman, dan } \\
\text { menyenangkan }\end{array}$ & 12 & 57. & 9 & $\begin{array}{c}42 . \\
8 \%\end{array}$ \\
\hline & Jumlah & 21 & 100 & 21 & 100 \\
$\%$
\end{tabular}

Sumber : Hasil analisis, 2018.

Nilai prosentase untuk "Penciptaan lingkungan yang bebas dari tindak kekerasan" berada pada angka " $57.2 \%$ " untuk yang berpendapat bahwa SMP Telkom Makassar telah menciptakan lingkungan yang bebas dari tindak kekerasan, dan " $42.8 \%$ \%" untuk yang berpendapat bahwa SMP Telkom Makassar belum menciptakan lingkungan yang bebas dari tindak kekerasan.

c. Menjamin keamanan, keselamatan dan kenyamanan peserta didik

Tabel 4. 16 Menjamin keamanan, keselamatan dan kenyamanan peserta didik

\begin{tabular}{|c|c|c|c|c|c|}
\hline \multirow[b]{3}{*}{ No } & \multirow{3}{*}{$\begin{array}{l}\text { Upaya yang } \\
\text { dilakukan } \\
\text { untuk } \\
\text { mencegah dan } \\
\text { menanggulangi } \\
\text { terjadinya } \\
\text { tindak } \\
\text { kekerasan }\end{array}$} & \multicolumn{4}{|c|}{ Alternatif } \\
\hline & & \multicolumn{2}{|c|}{ Ya } & \multicolumn{2}{|c|}{ Tidak } \\
\hline & & $\begin{array}{l}\text { Fre } \\
\text { kue } \\
\text { nsi }\end{array}$ & $\begin{array}{l}\text { Pro } \\
\text { sen } \\
\text { tase }\end{array}$ & $\begin{array}{l}\text { Fre } \\
\text { kue } \\
\text { nsi }\end{array}$ & $\begin{array}{l}\text { Pro } \\
\text { sen } \\
\text { tase }\end{array}$ \\
\hline 3. & $\begin{array}{l}\text { Menjamin } \\
\text { keamanan, } \\
\text { keselamatan } \\
\text { dan } \\
\text { kenyamanan } \\
\text { peserta didik }\end{array}$ & 17 & $\begin{array}{l}81 \\
\%\end{array}$ & 4 & $\begin{array}{l}19 \\
\%\end{array}$ \\
\hline & Jumlah & 21 & $\begin{array}{c}100 \\
\%\end{array}$ & 21 & $\begin{array}{c}100 \\
\%\end{array}$ \\
\hline
\end{tabular}

Sumber : Hasil analisis, 2018.

Nilai prosentase untuk "Penciptaan lingkungan yang bebas dari tindak kekerasan" berada pada angka "81 \%" untuk yang berpendapat bahwa SMP Telkom Makassar telah menciptakan lingkungan yang bebas dari tindak kekerasan, 
dan "19 \%" untuk yang berpendapat bahwa SMP Telkom Makassar belum menciptakan lingkungan yang bebas dari tindak kekerasan.

d. Melaporkan kepada orangtua/wali termasuk mencari informasi apabila ada dugaan/gejala akan terjadi tindak kekerasan

Tabel 4.17 Melaporkan kepada orangtua/wali termasuk mencari informasi apabila ada dugaan/gejala akan terjadi tindak kekerasan

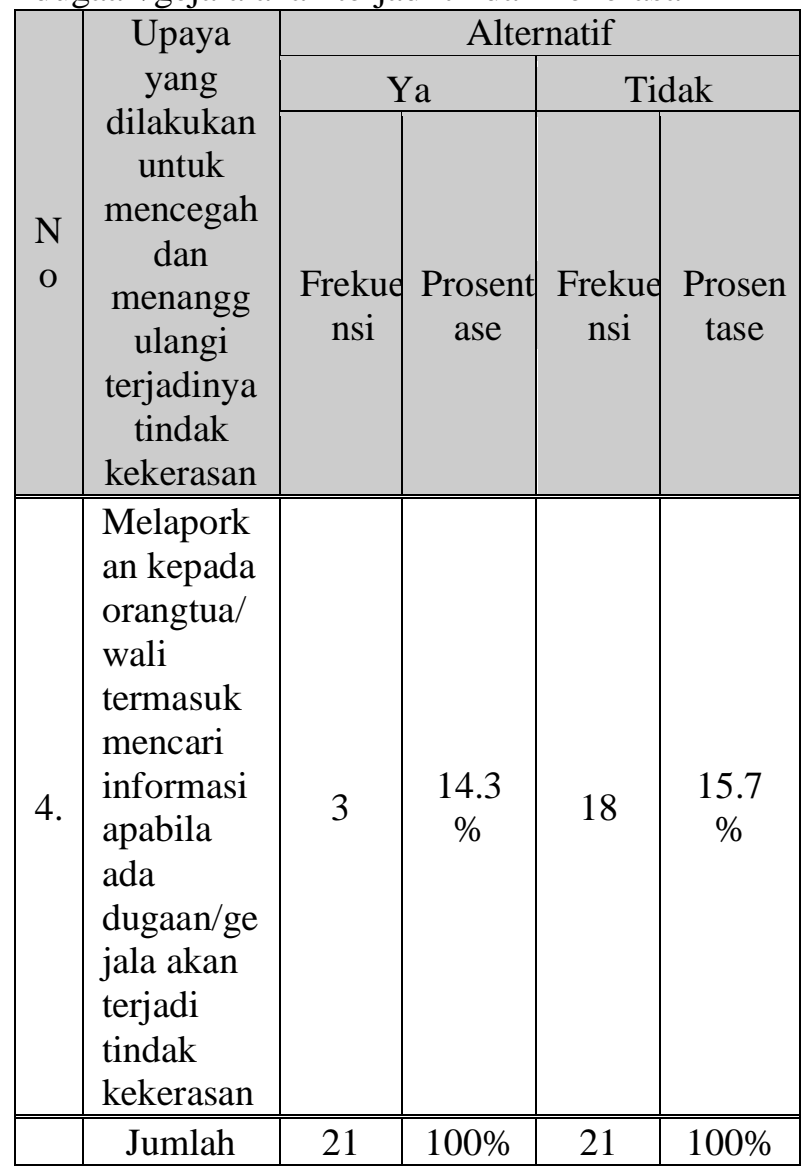

Sumber : Hasil analisis, 2018.

Nilai prosentase untuk "Penciptaan lingkungan yang bebas dari tindak kekerasan" berada pada angka "14.3\%" untuk yang berpendapat bahwa SMP Telkom Makassar telah menciptakan lingkungan yang bebas dari tindak kekerasan, dan "15.7\%" untuk yang berpendapat bahwa SMP Telkom Makassar belum menciptakan lingkungan yang bebas dari tindak kekerasan.

e. Menyusun dan menetapkan Prosedur Operasi Standar (POS) pencegahan tindak kekerasan yang mengacu pada pedoman yang ditetapkan Kementerian

Tabel 4.18 Menyusun dan menetapkan Prosedur Operasi Standar (POS) pencegahan tindak kekerasan yang mengacu pada pedoman yang ditetapkan Kementerian

\begin{tabular}{|c|c|c|c|c|c|}
\hline \multirow[b]{3}{*}{$\begin{array}{l}\mathrm{N} \\
\mathrm{o}\end{array}$} & \multirow{3}{*}{$\begin{array}{c}\text { Upaya } \\
\text { yang } \\
\text { dilakukan } \\
\text { untuk } \\
\text { mencegah } \\
\text { dan } \\
\text { menangg } \\
\text { ulangi } \\
\text { terjadinya } \\
\text { tindak } \\
\text { kekerasan }\end{array}$} & \multicolumn{4}{|c|}{ Alternatif } \\
\hline & & \multicolumn{2}{|c|}{$\mathrm{Ya}$} & \multicolumn{2}{|c|}{ Tidak } \\
\hline & & $\begin{array}{c}\text { Freku } \\
\text { ensi }\end{array}$ & $\begin{array}{c}\text { Prosen } \\
\text { tase }\end{array}$ & $\begin{array}{c}\text { Freku } \\
\text { ensi }\end{array}$ & $\begin{array}{c}\text { Prosen } \\
\text { tase }\end{array}$ \\
\hline 5. & $\begin{array}{l}\text { Menyus } \\
\text { un dan } \\
\text { menetap } \\
\text { kan } \\
\text { Prosedur } \\
\text { Operasi } \\
\text { Standar } \\
\text { (POS) } \\
\text { pencega } \\
\text { han } \\
\text { tindak } \\
\text { kekerasa } \\
\text { n yang } \\
\text { mengacu } \\
\text { pada } \\
\text { pedoma } \\
\text { n yang } \\
\text { ditetapk } \\
\text { an } \\
\text { Kemente } \\
\text { rian }\end{array}$ & 2 & $\begin{array}{c}14.2 \\
\%\end{array}$ & 19 & $\begin{array}{c}85.8 \\
\%\end{array}$ \\
\hline & Jumlah & 21 & $100 \%$ & 21 & $100 \%$ \\
\hline
\end{tabular}

Sumber : Hasil analisis, 2018.

Nilai prosentase untuk "Penciptaan lingkungan yang bebas dari tindak kekerasan" berada pada angka "14.2\%" untuk yang berpendapat bahwa SMP Telkom Makassar telah menciptakan lingkungan yang bebas dari tindak kekerasan, dan "85.8\%" untuk yang berpendapat bahwa SMP Telkom Makassar belum menciptakan lingkungan yang bebas dari tindak kekerasan.

f. Melakukan sosialisasi POS kepada peserta didik, pendidik, tenaga kependidikan, orangtua atau wali, komite sekolah, dan masyarakat Tabel 4.19 Melakukan sosialisasi POS kepada peserta didik, pendidik, tenaga kependidikan, orangtua atau wali, komite sekolah, dan masyarakat

\begin{tabular}{|l|c|l}
\hline $\mathrm{N}$ & Upaya & Alternatif \\
\hline
\end{tabular}




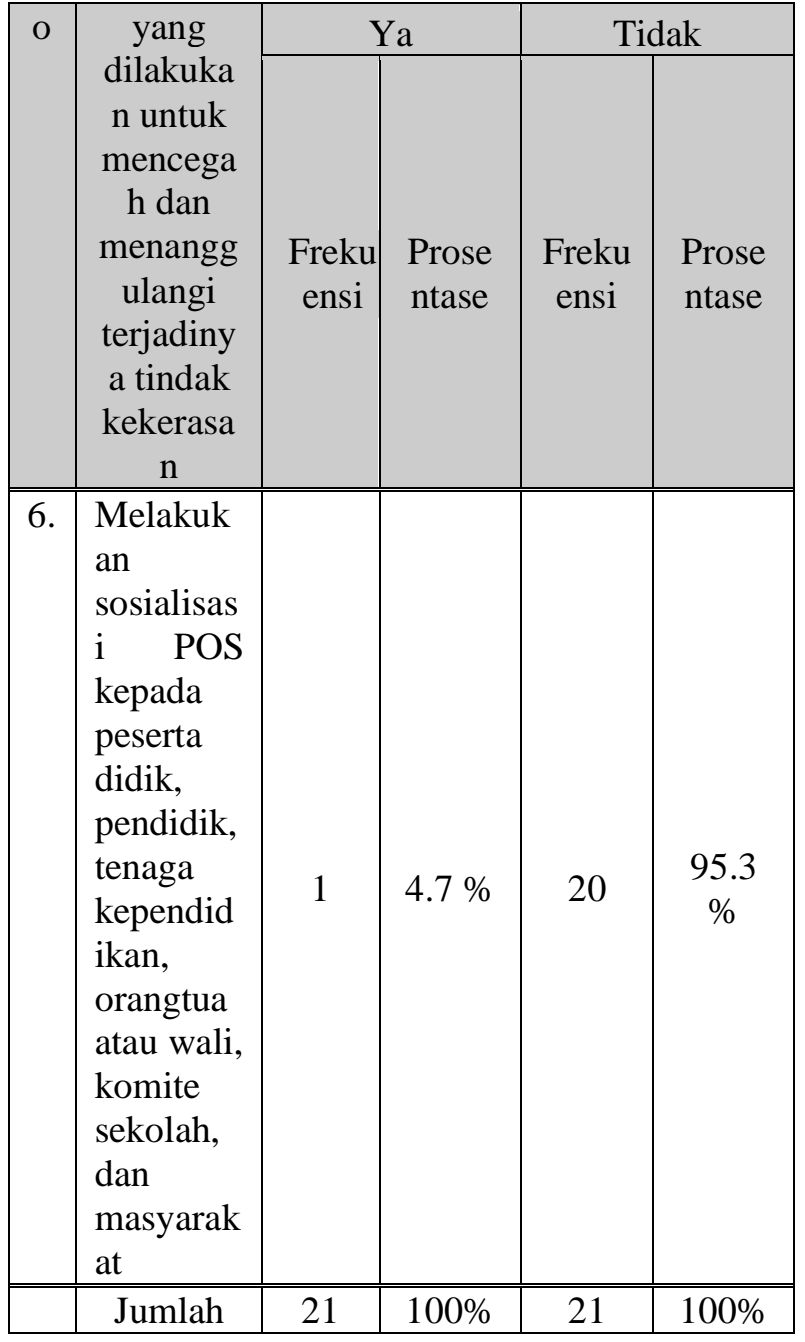

Sumber : Hasil analisis, 2018.

Nilai prosentase untuk "Penciptaan lingkungan yang bebas dari tindak kekerasan" berada pada angka "90.5\%" untuk yang berpendapat bahwa SMP Telkom Makassar telah menciptakan lingkungan yang bebas dari tindak kekerasan, dan " $0.5 \%$ " untuk yang berpendapat bahwa SMP Telkom Makassar belum menciptakan lingkungan yang bebas dari tindak kekerasan.

g. Menjalin kerjasama dengan lembaga psikologi, organisasi keagamaan, dan pakar pendidikan

Tabel 4.20 Menjalin kerjasama dengan lembaga psikologi, organisasi keagamaan, dan pakar pendidikan

\begin{tabular}{|c|c|c|c|c|c|}
\hline \multirow{3}{*}{$\begin{array}{l}\mathrm{N} \\
\mathrm{o}\end{array}$} & \multirow{3}{*}{$\begin{array}{c}\text { Upaya } \\
\text { yang } \\
\text { dilakuka } \\
\text { n untuk } \\
\text { mencega }\end{array}$} & \multicolumn{4}{|c|}{ Alternatif } \\
\hline & & \multicolumn{2}{|c|}{ Ya } & \multicolumn{2}{|c|}{ Tidak } \\
\hline & & $\begin{array}{c}\text { Freku } \\
\text { ensi }\end{array}$ & $\begin{array}{l}\text { Prose } \\
\text { ntase }\end{array}$ & $\begin{array}{c}\text { Freku } \\
\text { ensi }\end{array}$ & $\begin{array}{l}\text { Prose } \\
\text { ntase }\end{array}$ \\
\hline
\end{tabular}

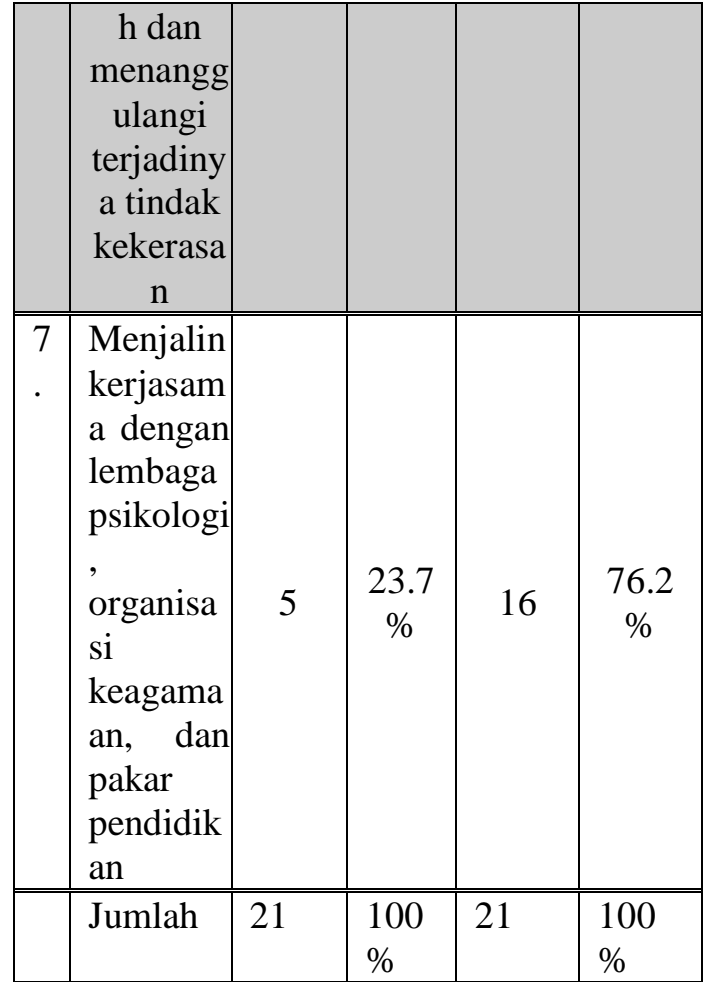

Sumber : Hasil analisis, 2018.

Nilai prosentase untuk "Penciptaan lingkungan yang bebas dari tindak kekerasan" berada pada angka "90.5\%" untuk yang berpendapat bahwa SMP Telkom Makassar telah menciptakan lingkungan yang bebas dari tindak kekerasan, dan " $0.5 \%$ " untuk yang berpendapat bahwa SMP Telkom Makassar belum menciptakan lingkungan yang bebas dari tindak kekerasan.

h. Membentuk tim pencegahan tindak kekerasan yang teridiri dari kepala sekolah, perwakilan guru, perwakilan siswa dan perwakilan orangtua/ wali

Tabel. 4.21 Membentuk tim pencegahan tindak kekerasan yang teridiri dari kepala sekolah, perwakilan guru, perwakilan siswa dan perwakilan orangtua/ wali

\begin{tabular}{|c|c|c|c|}
\hline $\mathrm{N}$ & Upaya & \multicolumn{2}{|c|}{ Alternatif } \\
\cline { 3 - 4 } $\mathrm{o}$ & yang & Ya & Tidak \\
\hline
\end{tabular}




\begin{tabular}{|c|c|c|c|c|c|}
\hline & $\begin{array}{c}\text { dilakukan } \\
\text { untuk } \\
\text { mencegah } \\
\text { dan } \\
\text { menanggu } \\
\text { langi } \\
\text { terjadinya } \\
\text { tindak } \\
\text { kekerasan }\end{array}$ & $\begin{array}{c}\text { Freku } \\
\text { ensi }\end{array}$ & $\begin{array}{c}\text { Prosent } \\
\text { ase }\end{array}$ & $\begin{array}{c}\text { Frekue } \\
\text { nsi }\end{array}$ & $\begin{array}{c}\text { Prosen } \\
\text { ase }\end{array}$ \\
\hline 8. & $\begin{array}{l}\text { Memben } \\
\text { tuk tim } \\
\text { pencega } \\
\text { han } \\
\text { tindak } \\
\text { kekerasa } \\
\text { n yang } \\
\text { teridiri } \\
\text { dari } \\
\text { kepala } \\
\text { sekolah, } \\
\text { perwakil } \\
\text { an guru, } \\
\text { perwakil } \\
\text { an siswa } \\
\text { dan } \\
\text { perwakil } \\
\text { an } \\
\text { orangtua } \\
\text { / wali }\end{array}$ & 3 & $\begin{array}{c}14.3 \\
\%\end{array}$ & 18 & $\begin{array}{c}15.7 \\
\%\end{array}$ \\
\hline & Jumlah & 21 & $100 \%$ & 21 & $100 \%$ \\
\hline
\end{tabular}

Sumber : Hasil analisis, 2018.

Nilai prosentase untuk "Penciptaan lingkungan yang bebas dari tindak kekerasan" berada pada angka "90.5\%" untuk yang berpendapat bahwa SMP Telkom Makassar telah menciptakan lingkungan yang bebas dari tindak kekerasan, dan " $0.5 \%$ " untuk yang berpendapat bahwa SMP Telkom Makassar belum menciptakan lingkungan yang bebas dari tindak kekerasan.

i. Memasang papan layanan pengaduan tindak kekerasan yang mudah di akses

Tabel 4.22 Memasang papan layanan pengaduan tindak kekerasan yang mudah di akses

\begin{tabular}{|c|c|c|c|c|c|}
\hline \multirow{3}{*}{$\begin{array}{l}\mathrm{N} \\
\mathrm{o}\end{array}$} & \multirow{3}{*}{$\begin{array}{c}\text { Upaya } \\
\text { yang } \\
\text { dilakukan } \\
\text { untuk } \\
\text { mencega }\end{array}$} & \multicolumn{4}{|c|}{ Alternatif } \\
\hline & & \multicolumn{2}{|c|}{ Ya } & \multicolumn{2}{|c|}{ Tidak } \\
\hline & & $\begin{array}{c}\text { Freku } \\
\text { ensi }\end{array}$ & $\begin{array}{c}\text { Prosen } \\
\text { ase }\end{array}$ & $\begin{array}{c}\text { Frekue } \\
\text { nsi }\end{array}$ & $\begin{array}{c}\text { Prosen } \\
\text { tase }\end{array}$ \\
\hline
\end{tabular}

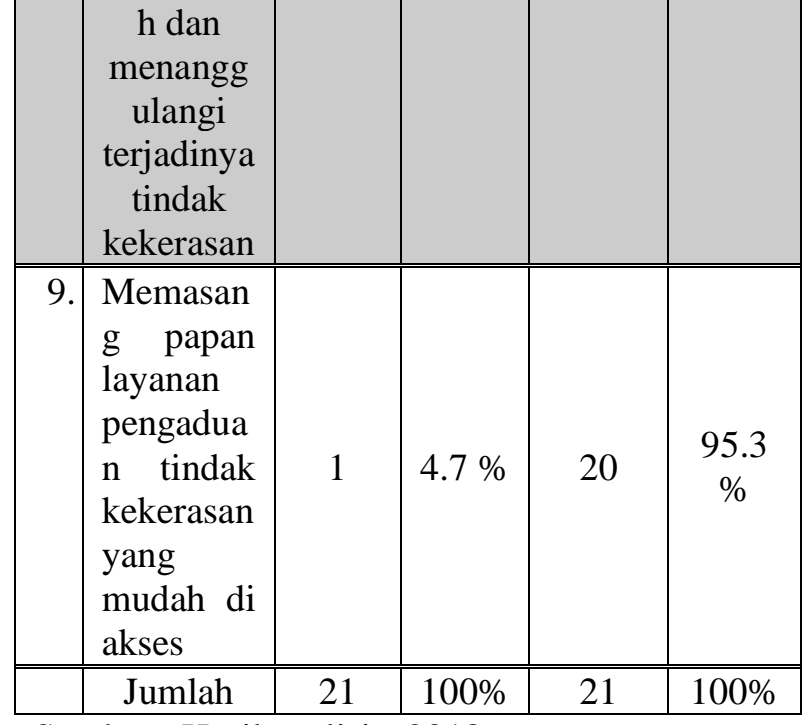

Sumber : Hasil analisis, 2018.

Nilai prosentase untuk "Penciptaan lingkungan yang bebas dari tindak kekerasan" berada pada angka "90.5\%" untuk yang berpendapat bahwa SMP Telkom Makassar telah menciptakan lingkungan yang bebas dari tindak kekerasan, dan " $0.5 \%$ " untuk yang berpendapat bahwa SMP Telkom Makassar belum menciptakan lingkungan yang bebas dari tindak kekerasan.

j. Membentuk tim pencegahan tindak kekerasan sesuai dengan kondisi dan kebutuhan satuan pendidikan
Tabel 4.23 Membentuk tim pencegahan tindak kekerasan sesuai dengan kondisi dan kebutuhan satuan pendidikan

\begin{tabular}{|c|c|c|c|c|c|}
\hline \multirow{3}{*}{$\mathrm{N}$} & Upaya & \multicolumn{4}{|c|}{ Alternatif } \\
\cline { 3 - 6 } $\mathrm{N}$ & $\begin{array}{c}\text { yang } \\
\text { dilakukan } \\
\text { untuk }\end{array}$ & \multicolumn{2}{|c|}{ Ya } & \multicolumn{2}{c|}{ Tidak } \\
\cline { 3 - 6 } & $\begin{array}{c}\text { Freku } \\
\text { mencegah } \\
\text { ensi }\end{array}$ & $\begin{array}{c}\text { Prosen } \\
\text { tase }\end{array}$ & $\begin{array}{c}\text { Frekue } \\
\text { nsi }\end{array}$ & $\begin{array}{c}\text { Prosen } \\
\text { tase }\end{array}$ \\
\hline
\end{tabular}




\begin{tabular}{|c|c|c|c|c|c|}
\hline & $\begin{array}{l}\text { menangg } \\
\text { ulangi } \\
\text { terjadinya } \\
\text { tindak } \\
\text { kekerasan }\end{array}$ & & & & \\
\hline $\begin{array}{l}1 \\
0 .\end{array}$ & $\begin{array}{l}\text { Membentu } \\
\mathrm{k} \quad \text { tim } \\
\text { pencegaha } \\
\mathrm{n} \text { tindak } \\
\text { kekerasan } \\
\text { sesuai } \\
\text { dengan } \\
\text { kondisi } \\
\text { dan } \\
\text { kebutuhan } \\
\text { satuan } \\
\text { pendidikan }\end{array}$ & 2 & $4.5 \%$ & 19 & $\begin{array}{c}90.5 \\
\%\end{array}$ \\
\hline & Jumlah & 21 & $100 \%$ & 21 & $100 \%$ \\
\hline
\end{tabular}

Sumber : Hasil analisis, 2018.

Nilai prosentase untuk "Penciptaan lingkungan yang bebas dari tindak kekerasan" berada pada angka "90.5\%" untuk yang berpendapat bahwa SMP Telkom Makassar telah menciptakan lingkungan yang bebas dari tindak kekerasan, dan " $0.5 \%$ " untuk yang berpendapat bahwa SMP Telkom Makassar belum menciptakan lingkungan yang bebas dari tindak kekerasan.

\section{Kendala yang Dihadapi Sehingga Tindak Kekerasan di SMP Telkom Makassar belum mampu di cegah}

Dari hasil penelitian melalui teknik wawancara akan dibahas mengenai kendala yang dihadapi oleh SMP Telkom Makassar, adapun hasil wawancara tersebut adalah sebagai berikut :

Berdasarkan hasil wawancara dengan bapak Agus Supriadi, Wali Kelas 8 A, menyatakan bahwa :

"Faktor internal sendiri kupikir masih menjadi penyebab belum optimalnya pencegahan dan penaggulangan tindak kekerasan di SMP Telkom adalah kurangnya sikap toleransi, sulitnya mengotrol emosi dan kurangnya sikap tanggungjawab, baik itu guru maupun siswa.." (wawancara Juli 2018 pukul 11.26 WITA)

$$
\text { Menurut pandangan tersebut }
$$

menjelaskan bahwa dibutuhkan toleransi, kontrol emosi, dan sikap tanggungjawab dari guru dan siswa untuk mencegah dan menanggulangi tindak kekerasan di lingkungan satuan pendidikan, khususnya SMP Telkom Makasassar.

Kemudian berdasarkan hasil wawancara dengan bapak Ridwan, Wali Kelas 7 B, menyatakan bahwa :

"Kurangnya pengetahuan dari guru bahwa kekerasan fisik maupun psikis tidak efektif untuk memotivasi atau merubah perilaku siswa, dan adanya tekanan pekerjaan seperti target yang harus di penuhi guru. Sedangkan dari siswa biasanya karena ingin diperhatikan, makanya tidak heran jika siswa berusaha memancing amarah guru atau siswa lainnya." (wawancara Juli 2018 pukul 13.33 WITA)

Hal tersebut menjelaskan bahwa kurangnya pengetahuan guru akan manfaat dari kekerasan terhadap siswa dan beban pekerjaan menjadi faktor internal mengapa kekerasan guru terhadap murid masih belum optimal untuk dicegah dan ditanggulangi. Sedangkan faktor internal dari siswa sendiri disebabkan oleh dimensi psikologis pertumbuhan remaja yaitu rasa ingin diperhatikan.

Selain itu, hal yang hampir sama dikemukakan oleh Devi Nur Hidayanti, peserta didik Kelas 8 A, yang menyatakan bahwa :

"Ketidakstabilan emosi remaja memiliki andil kenapa kekerasan dikalangan siswa masih sulit untuk dicegah. Ingin menonjolkan keberanian diri sendiri baik dihadapan teman maupun dihadapan guru untuk mendapat pengakuan bahwa dia berani." (Wawancara Juli 2018 puku 08.09 WITA)

Berdasarkan pandangan tersebut menjelaskan bahwa ketidakstabilan emosi siswa sebagai akibat dari masa pertumbuhan remaja menjadi faktor internal mengapa tindak kekerasan masih terjadi di lingkungan satuan pendidikan SMP Telkom Makassar.

Berdasarkan hasil wawancara dengan Rahmat Mursalim, peserta didik Kelas 9 C, menyatakan bahwa :

"Menurut saya faktor lingkungan tempat tinggalnya siswa menjadi faktor dominan mengapa tindak kekerasan di kalangan siswa masih saja terjadi." (Wawancara Juli 2018 pukul 09.02 WITA)

Berdasarkan hasil wawancara tersebut menjelaskan bahwa lingkungan tempat tinggal peserta didik mejadi salah satu faktor eksternal 
tindak kekerasan di lingkungan satuan pendidikan SMP Telkom Makassar.

Kemudian berdasarkan hasil wawancara dengan bapak Mursalim, Wali Kelas 7 F, menyatakan bahwa :

"Muatan kurikulum yang menekankan pada kemampuan kognitif dan cenderung mengabaikan kemampuan afektif kadang membuat suasana belajar jadi kering dan stressful, dan pihak guru pun kesulitan dalam menciptakan suasana belajar mengajar yang menarik, padahal mereka dituntut mencetak siswa-siswa berprestasi." (Wawancara Juli 2018 10.41 WITA)

Lebih lanjut, berdasarkan hasil wawancara dengan ibu Umi Kalsum, wali kelas 9 A, menyatakan bahwa :

"Tayangan-tayangan di televisi saya rasa turut memberikan andil mengapa siswa gampang sekali melakukan tindak kekerasan kepada kawannya, baik itu secara fisik maupun katakata. Apalagi gampangnya anak-anak mengakses internet membuat mereka tak terkontrol dalam menonton apapun. Ditambah lagi pengawasan orangtua yang lemah dalam mengontrol apa-apa saja yang di tonton oleh anaknya." (Wawancara Juli 201810.58 WITA) Berdasarkan hasil wawancara tersebut, kendala yang dihadapi sehingga tindak kekerasan di SMP Telkom Makassar belum mampu di cegah dapat disimpulkan sebagai berikut :

a. Faktor Internal

Faktor internal yang dimaksud disini adalah faktor yang berasal dari dalam diri individu itu sendiri, baik itu pendidik maupun peserta didik. Adapun faktor internal dari pendidik berupa :

1) kurangnya pengetahuan pendidik bahwa kekerasan baik fisik maupun psikis tidak efektif untuk memotivasi peserta didik atau merubah perilaku,

2) Adanya masalah psikologis yang menyebabkan hambatan dalam mengelola emosi hingga pendidik yang bersangkutan menjadi lebih sensitif dan reaktif.

Faktor internal dari peserta didik berupa :

1) Kurangnya sikap toleransi, sulit mengotrol emosi dan kurangnya sikap tanggungjawab

2) Masa pertumbuhan remaja yang dialami oleh peserta didik.

b. Faktor Eksternal
Faktor eksternal yang dimaksud disini adalah faktor yang berasal dari luar diri individu, baik itu guru maupun siswa. Faktor eksternal dari pendidik berupa adanya tekanan kerja atau target yang harus dipenuhi oleh pendidik dan faktor eksternal peserta didik adalah faktor lingkungan tempat tinggal peserta didik.

\section{PEMBAHASAN}

Berdasarkan hasil penelitiann yang telah diuraikan, maka pada bagian ini pembahasan hasil penelitan untuk mengetahui lebih lanjut mengenai (1) pemahaman guru-guru di SMP Telkom makassar tentang Permendikbud Nomor 82 Tahun 2015 (2) kendala yang dihadapi sehingga tindak kekerasan di SMP Telkom Makassar belum mampu di cegah (3) upaya yang dilakukan oleh SMP Telkom Makassar untuk mencegah dan menanggulangi terjadinya tindak kekerasan.

\section{Pemahaman satuan pendidikan di SMP Telkom Makassar terhadap Permendikbud Nomor 82 Tahun 2015}

Dari hasil penelitian melalui teknik wawancara tertutup akan dibahas mengenai tingkat pemahaman Pemahaman satuan pendidikan di SMP Telkom Makassar terhadap Permendikbud Nomor 82 Tahun 2015, adapun pembahasannya sebagai berikut :

Sekaitan hasil penelitian ditinjau dari aspek pemahaman satuan pendidikan yang tergolong rendah, hal ini tentu keadaan yang harus diperhatikan mengingat pencegahan dan penanggulangan tindak kekerasan dilingkungan satuan pendidikan merupakan kebutuhan yang sangat penting bagi satuan pendidikan dalam menjalani aktifitasnya sehari-hari. Khususnya dalam penelitian ini yang menjadi fokus dilihat dari guru sekaitan dua aspek dengan rendahnya pengetahuan dan pemahaman satuan pendidikan tentang Permendikbud No. 82 Tahun 2015 tentang pencegahan dan penanggulangan tindak kekerasan dilingkungan satuan pendidikan.

Dari hasil penelitian ini, tingkat pengetahuan dan pemahaman satuan pendidikan tentang Permendikbud No. 82 Tahun 2015 tentang pencegahan dan penanggulangan tindak kekerasan dilingkungan satuan pendidikan berada pada kategori kurang baik atau tergolong rendah dan hal ini bisa jadi menjadi pemicu permasalahan khususnya belum optimalnya 
pencegahan dan penanggulangan tindak kekerasan dilingkungan satuan pendidikan SMP Telkom Makassar, namun berdasar indeks tingkat respon, sosialisasi dan pendapat satuan pendidikan terhadap Permendikbud No. 82 Tahun 2015 tentang pencegahan dan penanggulangan tindak kekerasan dilingkungan satuan pendidikan yang tergolong baik, maka dari penelitan ini diharapkan kedepannya membaik dan segala permasalahan khususnya dalam pencegahan dan penanggulangan tindak kekerasan dilingkungan satuan pendidikan SMP Telkom Makassar makin membaik.

\section{Upaya yang dilakukan oleh SMP Telkom Makassar untuk mencegah dan menanggulangi terjadinya tindak kekerasan}

Upaya yang dilakukan dalam mencegah dan menanggulangi tindak kekerasan di lingkungan satuan pendidikan diperlukan guna menghadirkan solusi-solusi agar dapat tercipta lingkungan yang nyaman bagi pendidik dan peserta didik atau paling tidak dapat meminimalisir berbagai permasalahan dalam penanggulangan dan pencegahan tindak kekerasan dilingkungan satuan pendidikan. Adapun pembahasannya adalah sebagai berikut: Sekaitan hasil penelitian ditinjau dari upaya yang dilakukan oleh SMP Telkom Makassar yang tergolong masih belum menjadikan Permendikbud No. 82 Tahun 2015 sebagai acuan, hal ini tentu keadaan yang harus diperhatikan mengingat pencegahan dan penanggulangan tindak kekerasan dilingkungan satuan pendidikan merupakan kebutuhan yang sangat penting bagi satuan pendidikan dalam menjalani aktifitasnya sehari-hari. Khususnya dalam penelitian ini yang menjadi fokus dilihat dari pendidik sekaitan belum dijadikannya Permendikbud No. 82 Tahun 2015 pasal 7 sebagai acuan utama dalam upaya pencegahan dan penanggulangan tindak kekerasan dilingkungan satuan pendidikan.

Dari hasil penelitian ini, penciptaan lingkungan yang bebas dari tindak kekerasan, pembangunan lingkungan yang aman, nyaman, dan menyenangkan, serta jaminan keamanan, keselamatan dan kenyamanan peserta didik seperti yang terlihat dalam tabel telah berada pada kategori yang baik, maka dari penelitan ini diharapkan kedepannya membaik dan segala permasalahan khususnya dalam pencegahan dan penanggulangan tindak kekerasan dilingkungan satuan pendidikan SMP Telkom Makassar makin membaik. Namun pada pelaporan kepada orangtua/wali termasuk mencari informasi apabila ada dugaan/gejala akan terjadi tindak kekerasan, menyusun dan menetapkan Prosedur Operasi Standar (POS) pencegahan tindak kekerasan yang mengacu pada pedoman yang ditetapkan Kementerian, Melakukan sosialisasi POS kepada peserta didik, pendidik, tenaga kependidikan, orangtua atau wali, komite sekolah, dan masyarakat, menjalin kerjasama dengan lembaga psikologi, organisasi keagamaan, dan pakar pendidikan, Membentuk tim pencegahan tindak kekerasan yang teridiri dari kepala sekolah, perwakilan guru, perwakilan siswa dan perwakilan orangtua/ wali, memasang papan layanan pengaduan tindak kekerasan yang mudah di akses, serta membentuk tim pencegahan tindak kekerasan sesuai dengan kondisi dan kebutuhan satuan pendidikan berada pada kategori kurang baik yang berarti belum sesuai dengan Permendikbud No. 82 Tahun 2015 dan hal ini bisa jadi menjadi pemicu permasalahan khususnya belum optimalnya pencegahan dan penanggulangan tindak kekerasan dilingkungan satuan pendidikan SMP Telkom Makassar.

\section{Kendala Yang Dihadapi Sehingga Tindak Kekerasan di SMP Telkom Makassar Belum Mampu di Cegah}

Dari hasil penelitian melalui teknik wawancara terbuka akan dibahas mengenai kendala yang dihadapi sehingga tindak kekerasan di SMP Telkom Makassar belum mampu di cegah. Penyebab terkendalanya pencegahan dan penanggulangan tindak kekerasan di SMP Telkom ini akibat persoalan internal dan eksternal. Adapun penjelasannya adalah sebagai berikut :

\section{a. Faktor Internal}

1). Dari Guru

Ada beberapa faktor yang menyebabkan guru melakukan tindak kekerasan pada siswa, yaitu :

a) Kurangnya pengetahuan guru bahwa kekerasan baik fisik maupun psikis tidak efektif untuk memotivasi siswa atau merubah perilaku, malah beresiko 
menimbulkan trauma psikologis dan melukai harga diri siswa

b) Adanya masalah psikologis yang menyebabkan hambatan dalam mengelola emosi hingga guru yang bersangkutan menjadi lebih sensitif dan reaktif.

2). Dari siswa

a) Kurangnya sikap toleransi, sulit mengotrol emosi dan kurangnya sikap tanggungjawab pada siswa

b) Masa pertumbuhan remaja yang sedang dialami siswa menyebabkan mereka cenderung mencari perhatian dari orang-orang disekitarnya meskipun dengan cara-cara yang tidak sehat dan reaktif.

b. Faktor Eksternal

1) Adanya tekanan kerja atau target yang harus dipenuhi oleh guru, baik dari segi kurikulum, materi maupun prestasi yang harus dicapai siswa didiknya sementara kendala yang dirasakan untuk mencapai hasil yang ideal dan maksimal cukup besar

2) Faktor lingkungan tempat tinggal siswa sangat memberikan dampak dalam perilaku siswa sehari-hari disekolah

3) Tayangan-tayangan di televisi dan penggunaan internet yang tidak terkontrol juga memberikan andil dalam membentuk perilaku siswa sehari-hari disekolah

\section{SIMPULAN DAN SARAN}

\section{A. Kesimpulan}

Berdasarkan hasil analisis data beserta pembahasan mengenai implementasi Permendikbud No. 82 Tahun 2015 tentang pencegahan dan penanggulangan tindak kekerasan di lingkungan satuan pendidikan di SMP Telkom Makassar, dapat penulis simpulkan sebagai berikut :

1. Tingkat pemahaman satuan pendidikan di SMP Telkom makassar tentang Permendikbud Nomor 82 Tahun 2015 berada pada kategori kurang baik.

2. Prosedur penanganan tindak kekerasan yang terjadi di SMP Telkom Makassar belum sesuai dengan ketentuan yang ada di dalam Permendikbud No. 82 Tahun 2015.

3. Yang menjadi kendala sehingga tindak kekerasan di SMP Telkom Makassar belum mampu di cegah di sebabkan oleh dua faktor, yaitu faktor internal dan faktor eksternal. Faktor internal dari pendidik berupa (a) kurangnya pengetahuan pendidik bahwa kekerasan baik fisik maupun psikis tidak efektif untuk memotivasi peserta didik atau merubah perilaku, (b) Adanya masalah psikologis yang menyebabkan hambatan dalam mengelola emosi hingga pendidik yang bersangkutan menjadi lebih sensitif dan reaktif. Faktor internal dari peserta didik berupa (a) Kurangnya sikap toleransi, sulit mengotrol emosi dan kurangnya sikap tanggungjawab (b) Masa pertumbuhan remaja yang dialami oleh peserta didik. Sedangkan faktor eksternalnya dari pendidik berupa adanya tekanan kerja atau target yang harus dipenuhi oleh pendidik dan faktor eksternal peserta didik adalah faktor lingkungan tempat tinggal peserta didik.

\section{B. Saran}

Dari kesimpulan penelitian, maka diajukan saran sebagai berikut :

1. Kurang baiknya pemahaman guru-guru di SMP Telkom makassar tentang Permendikbud Nomor 82 Tahun 2015, maka diharapkan ada sosialisasi terlebih dahulu tentang Permendikbud ini.

2. Hendaknya SMP Telkom Makassar mengikuti langkah-langkah pencegahan dan penanggulangan tindak kekerasan sesuai yang ada di dalam Permendikbud No. 82 Tahun 2015.

3. Serta diharapkan faktor internal dan faktor ekseternal ini benar-benar diperhatikan dengan seksama dan ditindaklanjuti tak sekedar untuk hasil temuan melainkan sadar akan manfaat dari pencegahan dan penanggulangan tindak kekerasan dilingkungan satuan pendidikan itu sendiri.

\section{DAFTAR RUJUKAN}

\section{A. Buku}

Abdul Wahab, Solichin. 2004. Analisis Kebijaksanaan, Dari Formulasi Ke Implementasi Kebijakan Negara. Jakarta : Bumi Aksara. 
Abu Huraerah, 2006, Kekerasan terhadap Anak, Bandung : Nuansa

Anwar, Yesmil, 2004, Saat Menuai Kejahatan : Sebuah Pendekatan Sosiokultral Kriminologi Hukum, Bandung : UNPAD Press.

Barker, Robert L, 1987, The Social Work Dictionary, National Assosiation of Social Workers, Maryland : Silver Spring

Carl E. van Horn dan Donald S. van Meter, 1975, Model-model dalam Kebijakan Implmentasi, Yogyakarta

Edward, George C, 1990, Publicy Policy Implementing, Jai Press Inc, LondonEngland : Malcolm L

Galtung, Johan. 2003. Studi Perdamaian : Perdamaian dan Konflik Pembangunan dan Peradaban, Surabaya : Pustaka Eureka

Grindle, Merilee S. 1980. Politics and Policy Implementation in The Third World. New Jersey: Princeton University Press.

Guntur Setiawan, 2004, Impelemtasi dalam Birokrasi Pembangunan, Jakarta : Balai Pustaka.

Harsono, Hanifah, 2002, Implementasi Kebijakan dan Politik, Jakarta : Grafindo Jaya.

Herkutanto. 1998. Kekerasan Terhadap Perempuan dan Sistem Hukum Pidana, Pendekatan dari Sudut Pandang Kedokteran. Makalah dalam lokakarya Kekerasan Terhadap Perempuan dan Sistem Hukum Pidana, Suatu Pembahasan Kritis. Jakarta.

Ita F Nadia. 1998. Kekerasan terhadap perempuan dari perspekrif gender (kekerasan terhadap perempuan, lokakarya kesehatan perempuan). Jakarta : Yayasan Lembaga Konsumen Indonesia dan The Ford Foundation.

Mazmanian, Daniel A dan Sabatier, Paul A, 1983, Implementation and Publicy, USA : Foresman and Company.

Nurani, Soyomukti. 2010. Teori-teori pendiddikan"Tradisional, Neoliberal, Marxis sosialis, Postmodern". Yogyakarta : AR-RUZ MEDIA GROUP

Nurdin Usman, 2002, Konteks Implementasi Berbasis Kurikulum,Jakarta : Grasindo.. 2005, Kamus Besar Bahasa Indonesia. Jakarta : Departemen Pendidikan Nasional
Purwanto dan Suliyastuti, 1991, Analisis Kebijakan dari Formulasi ke Implementasi Kebijakan, Jakarta : Bumi Aksara.

Riant Nugroho. (2004) Kebijakan Publik: Formulasi, Implementasi, dan Evaluasi, Jakarta : PT. Elex Media Komputindo.

Ripley, Rendal B. And Franklin, Grace A, 1986, Policy Implementation and Bureaucracy, second edition, Chicago-Illonis : the Dorsey Press

Santoso, Topo. 2002. Kriminilogi, Jakarta : Grafindo Persada

Sampurna, Budi. 2003. Perempuan, kekerasan dan hukum.Yogyakarta : UII Press.

Setiawan, Guntur, 2004, Implementasi dalam

Birokrasi Pembangunan, Jakarta : Balai Pustaka.

Soesilo, 1980, KUHP serta Komentarnya Lengkap Pasal Demi Pasal, Bogor : Politeia.

Subarsono, 2006. Implementasi kebijakan Daerah, Bandung : Lembaga penelitian Universitas Padjajaran,

Sujono, Soekanto, 1987, Kriminologi (Pengantar Sebab-Sebab Kejahatan), Bandung: Politea.

Syaukani, dkk, 2004, Otonomi Daerah Dalam Negara Kesatuan, Yogyakarta : Pustaka Pelajar.

Usman, Nurdin, 2002, Konteks Implementasi Berbasis Kurikulum, Jakarta : Grasindo.

Zaitunah, Subhan. 2004. Kekerasan Terhadap Perempuan. Pustaka Pesantren: Yogyakarta.

\section{B. Undang-Undang}

UU RI No. 20 Tahun 2003 tentang Sistem Pendidikan Nasional

UU RI No. 23 Tahun 2003 tentang Perlindungan Anak

UU RI No. 35 Tahun 2014 tentang Perlindungan Anak

Permendikbud No. 82 Tahun 2015 Tentang Pencegahan dan Penanggulangan Tindak Kekerasan di Lingkungan Satuan Pendidikan.

\section{Internet}

[1]"Anak di Indonesia yang mengalami kekerasan di sekolah" melalui http://news.liputan6.com/read/2191106/su rvei-icrw-84-anak-indonesia-alamikekerasan-di-sekolah dikakses pada 
Phinisi Integration Review. Vol 1(2) Agustus 2018

tanggal 11 Januari 2018 pukul 10.17 WITA

[2]"Faktor Penyebab Terjadinya Kekerasan" melalui http://economistsuweca.blogspot.com/2010/09/budayakekerasan-yang-menguat-apa.html diakses pada tanggal 11 Januari 2018 pukul 11.23 WITA 